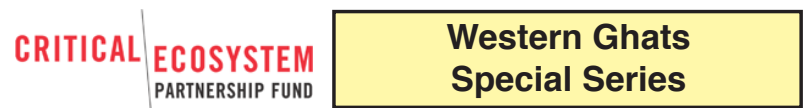

\title{
Freshwater fish fauna of Krishna River at Wai, northern Western Ghats, India
}

\author{
Sanjay S. Kharat ${ }^{1}$, Mandar Paingankar ${ }^{2} \&$ Neelesh Dahanukar ${ }^{3}$ \\ ${ }^{1}$ Department of Zoology, Modern College of Arts, Science and Commerce, Ganeshkhind, Pune, Maharashtra 411007, India \\ 2,3 Zoo Outreach Organization, 96 Kumutham Nagar, Villankurichi Road, Coimbatore, Tamil Nadu 641035, India \\ ${ }^{3}$ Indian Institute of Science Education and Research, Sai Trinity, Garware Circle, Pune, Maharashtra 411021, India \\ Email: ${ }^{1}$ kharat.sanjay@gmail.com, ${ }^{2}$ mandarpaingankar@gmail.com, ${ }^{3}$ n.dahanukar@iiserpune.ac.in (corresponding author)
}

Abstract: Freshwater fish fauna of the Krishna River at Wai, and the Dhom reservoir upstream of Wai, was studied. Fifty one species belonging to 14 families and 33 genera were recorded 13 endemic to the Western Ghats and two to the Krishna River system. Moderate to rare populations were found for six globally threatened species: Gonoproktopterus curmuca, Labeo potail, Schismatorhynchos nukta, Tor khudree, T. mussullah and Parapsilorhynchus discophorus. Fish in this area are unde threat due to two introduced species and five transplanted species, and due to other anthropogenic activities such as overfishing and organic and inorganic pollution of the river. Site based conservation action plans are needed for conservation of rare and threatened fish in this area.

Keywords: Freshwater fish fauna, Krishna River system, Threats.

Date of publication (online): 26 June 2012

Date of publication (print): 26 June 2012

ISSN 0974-7907 (online) | 0974-7893 (print)

Editor: W. Vishwanath

Manuscript details:

Ms \# 02796

Received 05 May 2011

Final revised received 08 April 2012

Finally accepted 21 May 2012

Citation: Kharat S.S., M. Paingankar \& N. Dahanukar (2012). Freshwater fish fauna of Krishna River at Wai, northern Western Ghats, India Journal of Threatened Taxa 4(6): 2644-2652.

Copyright: @ Sanjay S. Kharat, Mandar Paingankar \& Neelesh Dahanuka 2012. Creative Commons Attribution 3.0 Unported License. JoTT allows unrestricted use of this article in any medium for non-profit purposes, reproduction and distribution by providing adequate credit to the authors and the source of publication.

Acknowledgements: We are thankful to Dr. R.M. Sharma, Officer-incharge, and Shrikant Jadhav, Zoological Survey of India, Western Regiona Center, Akurdi, Pune, for encouragement and helpful discussion. The study was self funded. The CEPF-funded freshwater assessment of the Western Ghats encouraged us to publish this work. We duly acknowledge the help from CEPF for publication of this article.

\section{OPEN ACCESS | FREE DOWNLOAD (C) (i) ৫)}

Krishna River originates in Wai Taluka, Satara District, Maharashtra, India. The river flows west-east and the first major dam along its course is Dhom Dam, while the first major city is Wai. Some studies are available on the fish fauna of Krishna River at Wai and Dhom reservoir. Silas (1953) recorded nine species of freshwater fish from the river at Wai. Jayaram (1995) studied the entire Krishna River system and mentioned that collections were made from both Dhom reservoir and Krishna River at Wai. However, he did not provide a separate checklist of fish in this area. As an offshoot of the same work, Srithar \& Jayaram (1990) described a species, Salmophasia longicauda, and suggested that both $S$. longicauda and an allied species $S$. novacula are found in the fish catches of Dhom reservoir. Arunachalam et al. (2002) recorded 14 species of freshwater fish from Dhom reservoir. Taken together, these studies list 22 fish species in this area, which is an under representation compared to checklists from other tributaries of the Krishna River system (Kharat et al. 2003; Jadhav et al. 2011; Dahanukar et al. 2012). There is no documentation of threats to fish species in this area. In the present work we have studied the fish fauna of both Dhom reservoir and Krishna River at Wai in order to document both diversity and threats.

Fish were collected from Krishna River at Dhom

This article forms part of a special series on the Western Ghats of India disseminating the results of work supported by the Critical Ecosystem Partnership Fund (CEPF), a joint initiative of l'Agence Française de Développement, Conservation International, the Global Environment Facility, the Government of Japan, the MacArthur Foundation and the World Bank. A fundamental goal of CEPF is to ensure civil society is engaged in biodiversity conservation. Implementation of the CEPF investment program in the Western Ghats is led and coordinated by the Ashoka Trust for Research in Ecology and the Environment (ATREE). 


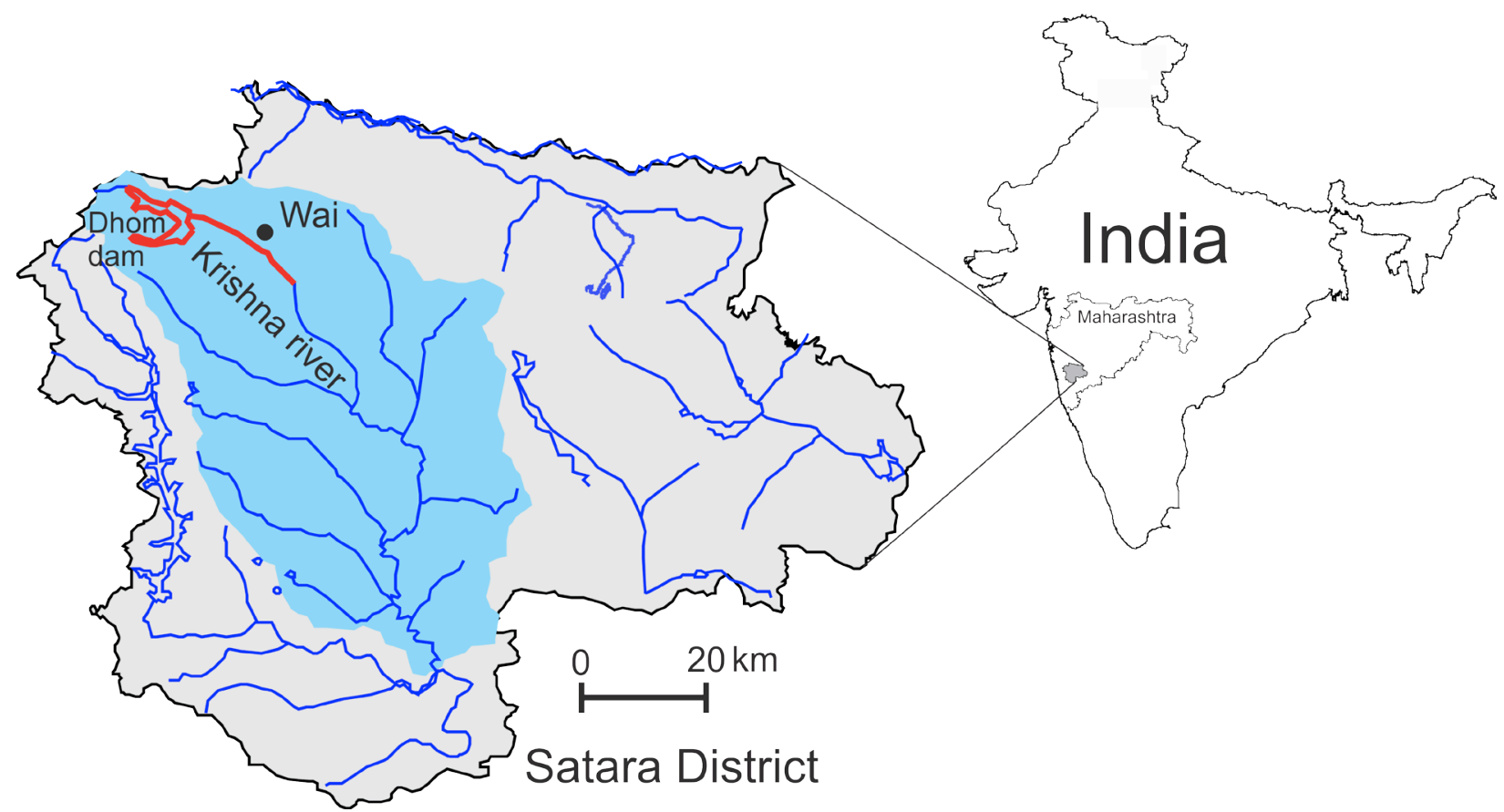

Image 1. Satara District is shown in grey. Sky blue area is the hydrobasin. Red line highlights the area considered for present study.

reservoir $\left(17.981^{\circ} \mathrm{N} \& 73.800^{\circ} \mathrm{E}\right)$ and from an approximately $15 \mathrm{~km}$ stretch between Dhom Dam and downstream of Wai $\left(17.930^{\circ} \mathrm{N} \& 73.922^{\circ} \mathrm{E}\right.$ ) (Image 1). Study was carried out for two years from May 2009 to April 2011. Fish were collected from local fishermen and local markets at Wai $\left(17.952^{\circ} \mathrm{N} \& 73.887^{\circ} \mathrm{E}\right)$. Only one or two specimens of each species were preserved while remaining specimens were identified in the field. Large sized common fish species and introduced fish species were not collected. Collected specimens were preserved in $4 \%$ formaldehyde and their identification was confirmed using available literature (Jayaram 1991; 2010; Jayaram \& Dhas 2000; Jayaram \& Sanyal 2003; Menon 1987; Talwar \& Jhingran 1991). Collected fish specimens are deposited in the Zoological Survey of India, Western Regional Centre, Akurdi, Pune, under the accession numbers from $\mathrm{P} / 2628$ to $\mathrm{P} / 2665$. Assuming that the fishing effort for a given type of net (gill net or drag net) was constant, relative abundance of the fish (for each type of net separately) was grossly categorized into four discrete categories, viz: abundant (76-100\% of the total catch), common (51-75\% of the total catch), moderate (26-50\% of the total catch) and rare (1-25\% of the total catch). Category for different species was determined for each catch separately and the most consistent category for a given species was chosen.

A total of 51 fish species belonging to 14 families and 35 genera were recorded (Table 1). Of these, 15 fish species are endemic to the Western Ghats of India while five are endemic to the Krishna River system. Out of a total 51 species, 49 fish species were recorded from Krishna River at Wai while 42 fish species were recorded from Dhom reservoir. Abundance-wise distribution suggests that Krishna River at Wai hosts 11 abundant, six common, 20 moderate and 12 rare fish species. Similarly, in Dhom reservoir, there are five abundant, 14 common, 16 moderate and seven rare fish species.

Of the nine species of freshwater fish recorded by Silas (1953) from Krishna River at Wai (Table 2), we could record all species. However, of the 14 species recorded by Arunachalam et al. (2002) from Dhom reservoir (Table 2), we could not record four species, namely Puntius conchonius, Indoreonectes evezardi, Nemachilichthys ruppelli and Eugnathogobius oligactis. Even though Srithar \& Jayaram (1990) recorded both Salmophasia longicauda and S. novacula from the Dhom reservoir, we could not distinguish two separate species in the fish catches. Therefore, following the synonymization of $S$. longicauda with $S$. novalula by Menon (1999) and Eschmeyer (2012), we 
Table 1. List of freshwater fish from Krishna River.

\begin{tabular}{|c|c|c|c|c|}
\hline \multirow[b]{2}{*}{ Family/Species ${ }^{a}$} & \multicolumn{2}{|c|}{ Abundance ${ }^{b}$} & \multirow[b]{2}{*}{ Remarks $^{c}$} & \multirow{2}{*}{$\begin{array}{l}\text { IUCN Redlist } \\
\text { status }^{d}\end{array}$} \\
\hline & $\begin{array}{c}\text { Krishna River } \\
\text { at Wai }\end{array}$ & Dhom reservoir & & \\
\hline \multicolumn{5}{|l|}{ Notopteridae } \\
\hline Notopterus notopterus (Pallas, 1769) & C & $\mathrm{C}$ & & LC \\
\hline \multicolumn{5}{|l|}{ Cyprinidae } \\
\hline Barilius barna (Hamilton, 1822) & M & - & & LC \\
\hline Catla catla (Hamilton, 1822) & $\mathrm{R}$ & C & $\mathrm{T}$ & \\
\hline Cirrhinus fulungee (Sykes, 1839) & M & M & & LC \\
\hline Cirrhinus mrigala (Hamilton, 1822) & $\mathrm{R}$ & C & $\mathrm{T}$ & \\
\hline Cirrhinus reba (Hamilton, 1822) & M & M & & LC \\
\hline Danio malabaricus (Jerdon, 1849) & $\mathrm{R}$ & - & & LC \\
\hline Garra mullya (Sykes, 1839) & A & A & & LC \\
\hline Gonoproktopterus curmuca (Hamilton, 1807) ${ }^{d}$ & A & A & WGE & EN \\
\hline Hypophthalmichthys molitrix (Valenciennes, 1844) & - & M & $\mathrm{T}$ & \\
\hline Labeo rohita (Hamilton, 1822) & $\mathrm{R}$ & M & $\mathrm{T}$ & \\
\hline Labeo potail (Sykes, 1839) & $\mathrm{R}$ & $\mathrm{R}$ & WGE & EN \\
\hline Osteobrama vigorsii (Sykes, 1839) & $\mathrm{R}$ & M & & LC \\
\hline Puntius cf. amphibius (Valenciennes, 1842) & M & M & & DD \\
\hline Rohtee ogilbii (Sykes, 1839) & $R$ & $\mathrm{R}$ & WGE & LC \\
\hline Salmophasia boopis (Day, 1874) & A & $\mathrm{C}$ & WGE & LC \\
\hline Salmophasia novacula (Valenciennes, 1840) ${ }^{f}$ & A & A & WGE & LC \\
\hline Schismatorhynchos nukta (Sykes, 1839) & $\mathrm{R}$ & $\mathrm{R}$ & WGE & EN \\
\hline Tor khudree (Sykes, 1839) & M & $\mathrm{C}$ & & EN \\
\hline Tor mussullah (Sykes, 1839) & $\mathrm{R}$ & $\mathrm{R}$ & WGE & EN \\
\hline \multicolumn{5}{|l|}{ Parapsilorhynchidae } \\
\hline Parapsilorhynchus discophorus Hora, 1921 & M & - & WGE & VU \\
\hline Parapsilorhynchus tentaculatus (Annandale, 1919) & M & - & & LC \\
\hline \multicolumn{5}{|l|}{ Balitoridae } \\
\hline Acanthocobitis mooreh (Sykes, 1839) ${ }^{f}$ & M & - & & LC \\
\hline Noemacheilus anguilla Annandale, 1919 & M & - & WGE, KRE & LC \\
\hline Schistura denisoni Day, 1867 & C & - & & LC \\
\hline \multicolumn{5}{|l|}{ Cobitidae } \\
\hline Lepidocephalichthys thermalis (Valenciennes, 1846) & A & - & & LC \\
\hline \multicolumn{5}{|l|}{ Bagridae } \\
\hline Mystus bleekeri (Day, 1877) & M & M & & LC \\
\hline
\end{tabular}




\begin{tabular}{|c|c|c|c|c|}
\hline \multirow[b]{2}{*}{ Family/Species ${ }^{a}$} & \multicolumn{2}{|c|}{ Abundance $^{\mathrm{b}}$} & \multirow[b]{2}{*}{ Remarks $^{c}$} & \multirow{2}{*}{$\begin{array}{l}\text { IUCN Redlist } \\
\text { status }^{d}\end{array}$} \\
\hline & $\begin{array}{c}\text { Krishna River } \\
\text { at Wai }\end{array}$ & Dhom reservoir & & \\
\hline \multicolumn{5}{|l|}{ Claridae } \\
\hline Clarias gariepinus (Burchell, 1822) & M & M & 1 & \\
\hline \multicolumn{5}{|l|}{ Belonidae } \\
\hline Chanda nama Hamilton, 1822 & A & $\mathrm{C}$ & & LC \\
\hline Parambassis baculis (Hamilton, 1822) & $\mathrm{C}$ & M & & LC \\
\hline Parambassis ranga (Hamilton, 1822) & M & M & & LC \\
\hline \multicolumn{5}{|l|}{ Cichlidae } \\
\hline \multicolumn{5}{|l|}{ Channidae } \\
\hline Channa gachua (Hamilton, 1822) & $\mathrm{R}$ & $\mathrm{R}$ & & LC \\
\hline Channa marulius (Hamilton, 1822) & $\mathrm{R}$ & M & & LC \\
\hline Channa punctata (Bloch, 1793) & M & M & & LC \\
\hline \multicolumn{5}{|l|}{ Mastecembalidae } \\
\hline Mastacembelus armatus (Lacepède, 1800) & $A$ & $A$ & & LC \\
\hline
\end{tabular}

a Taxonomic status as per Jayaram (2010) except where mentioned.

${ }^{\mathrm{b}}$ Abundance categories: A - abundant, C - common, M - moderate, R - rare, - - absent.

' WGE - Western Ghats endemic; KRE - Krishna river system endemic; I - introduced; T - transplanted

d IUCN (2011). EN - Endangered, NT - Near Threatened, LC - Least Concern, NE - Not Evaluated, DD - Data Deficient. Statuses for introduced/ transplanted species are not provided.

e Gonoproktopterus kolus is considered as synonym of G. curmuca (Jayaram 2010). However, if they are proved to be different, then our species should be considered as G. kolus as per Jayaram (1991) and the threat status of the fish will be VU as per Raghavan \& Ali (2011).

f Jayaram (2010) has listed this species under both Gonoproktopterus and Puntius. Because of the uncertainty, we have put the species under Puntius following Jayaram (1991).

g Species spellings as per Eschmeyer (2012)

have recorded only $S$. novacula from the study area. Thus, currently the total number of freshwater fish species known from Krishna River at Wai area is 55 .

Six species found in Krishna River at Wai and Dhom reservoir, viz., Gonoproktopterus curmuca, Labeo potail, Parapsilorhynchus discophorus, Schismatorhynchos nukta, Tor khudree and $T$. mussullah, (Image 2) are considered as globally threatened species, while two other species, Mystus malabaricus and Ompok bimaculatus, are considered as Near Threatened (IUCN 2011). Current study area holds an abundant to moderate to rare populations of these species.

Labeo potail was assessed as Endangerd (EN) based on a conservative estimate of global population decline of this species by $50-60 \%$ in the last 10 years caused by decline in the habitat quality owing to organic and inorganic pollution of rivers, harvesting of fish for consumption and competition created by transplanted carps (Dahanukar 2011a). Labeo potail is found rarely in both the Dhom reservoir and the downstream Krishna River in the study area and the species is facing similar stressors mentioned before. Raghavan (2011) assessed Tor khudree as EN owing to its high exploitation as a food fish, which might have resulted in drastic declines in the population of this species by more than $60 \%$ in the last 10 years. Raghavan et al. (2011) showed that the harvesting of this species from the wild populations is unsustainable and suggested that if conservation actions directed towards the species are not implemented the species might face a drastic reduction in the recent future. This species is found in moderate numbers in the Krishna River at Wai and is common in the Dhom reservoir. Nevertheless, the species is highly preferred as a food fish and fetches a good value in the fish market. Therefore, it is likely that the species could be under fishing pressure. Another allied species Tor mussullah is assessed as EN since it exists in the Western Ghats as severely fragmented populations and the population of this species is declining severely in most parts of its current distribution due to habitat modifications 
Table 2. Species recorded in previous studies.

\begin{tabular}{|l|c|c|}
\hline \multirow{2}{*}{ Species } & Silas (1953) & Arunachalam et al. (2002) \\
\cline { 2 - 3 } & Krishna River at Wai & Dhom reservoir \\
\hline Gonoproktopterus curmuca & + & - \\
\hline Puntius conchonius & - & + \\
\hline Gonoproktopterus jerdoni & + & + \\
\hline Puntius ticto & + & + \\
\hline Tor khudree & - & - \\
\hline Tor mussullah & + & + \\
\hline Salmophasia boopis & - & - \\
\hline Barilius barna & + & - \\
\hline Barilius bendelisis & + & + \\
\hline Devario aequipinnatus & - & + \\
\hline Rasbora daniconius & - & + \\
\hline Garra mullya & + & + \\
\hline Parapsilorhynchus tentaculatus & - & + \\
\hline Indoreonectes evezardi & - & + \\
\hline Nemachilichthys ruppelli & - & + \\
\hline Schistura denisoni & + & + \\
\hline Lepidocephalichthys thermalis & - & + \\
\hline Glossogobius giuris & - & + \\
\hline Eugnathogobius oligactis & - & + \\
\hline Channa punctatus & - & + \\
\hline Mastacembelus armatus & - & + \\
\hline
\end{tabular}

* Key: + = present, - = absent.

caused by pollution, heavy harvest of the species and competition created by the introduced alien species (Dahanukar \& Raghavan 2011). Tor mussullah is a very rare species in the current study area.

Discussions with fishermen in this area indicate that populations of Schismatorhynchos nukta have declined drastically in the recent past. Similar concerns were raised by Ghate et al. (2002) for this species from other tributaries of the Krishna River system. Ghate et al. (2002), Kharat et al. (2003) and Dahanukar et al. (2012) suspected pollution of the rivers and heavy harvest of the fish resources as possible causes for decline of this species from other rivers. On similar lines, we think that heavy harvesting of all large carps including $S$. nukta is a possible threat to fish fauna of Krishna River at Wai. Jayaram (1995) suggested that S. nukta is not much preferred as food. This is also true in the current study area because this species had relatively low demand as compared to other carps. Therefore, we think that the heavy harvest of this species could be attributed to unintentional catches along with other major carps. Competition created by other introduced carps like Catla catla, Cirrhinus mrigala and Labeo rohita could also be a possible threat to the species as it shares the same niche. Based on the same stressors and the fact that the population of this species is declining drastically, this species is assessed as EN (Dahanukar 2011c).

An endemic species of northern Western Ghats Parapsilorhynchus discophorus is assessed as Vulnerable(VU) owing to the fact that breeding habitats of the species on the mountain tops are threatened by habitat modification due to recreational activities (Dahanukar 2011b). The species is found in moderate numbers in the small streams draining in the Krishna River at Wai. Increasing urbanization, tourism and recreational activities in the mountain tops near this area, especially at Pachgani and Mahabaleshwar, are likely to affect the breeding habitats of the species.

Commenting on the threat status of Gonoproktopterus curmuca is not as easy as other species in this area. Abraham (2011) assessed 


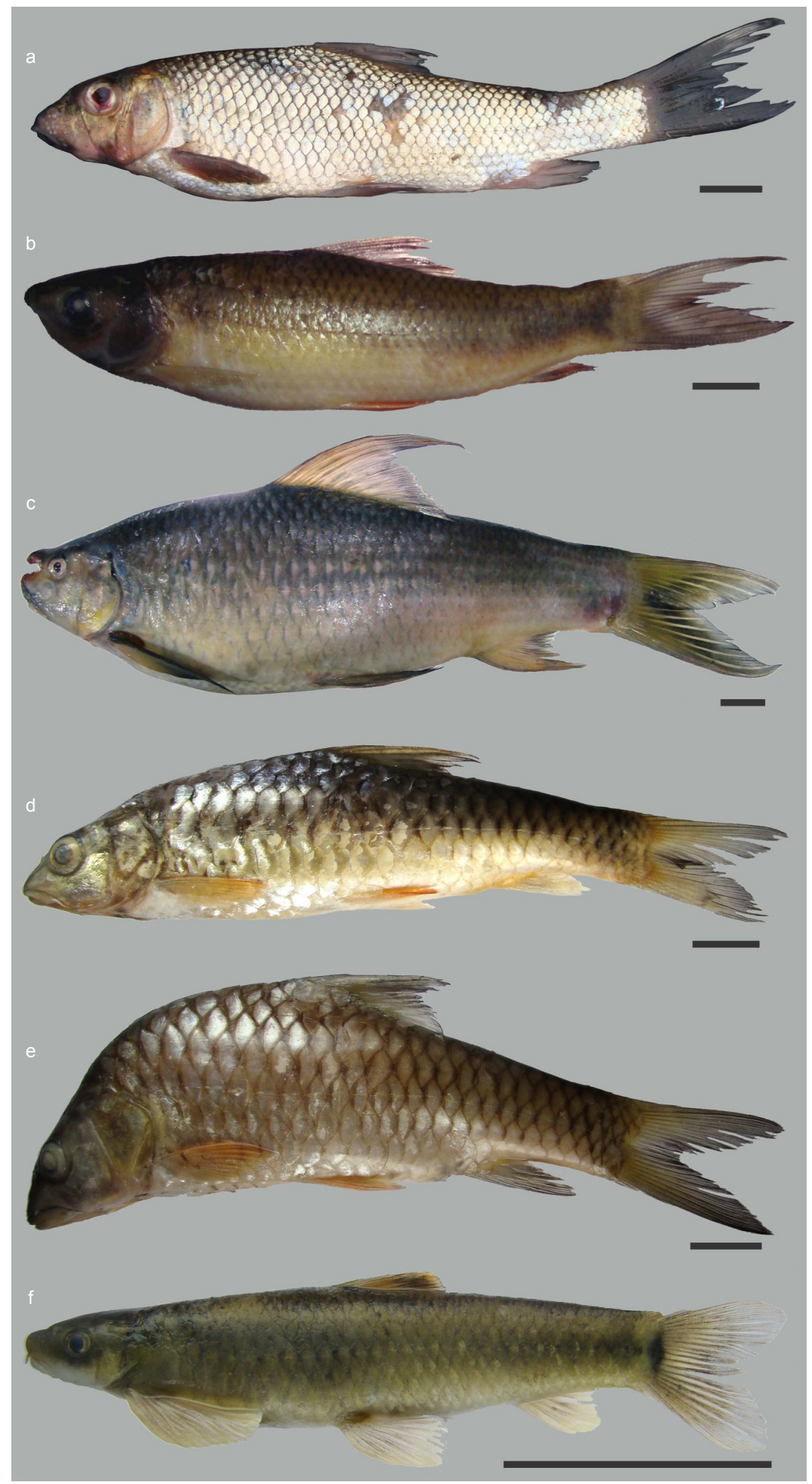

Image 2. Globally threatened fish species found in Krishna River at Wai.

a - Gonoproktopterus curmuca; b - Labeo potail; c - Schismatorhynchos nukta; d - Tor mussullah; e - Tor khudree; f - Parapsilorhynchus discophorus. Scale bar indicates $2 \mathrm{~cm}$.

Journal of Threatened Taxa | www.threatenedtaxa.org | June 2012 | 4(6): 2644-2652 

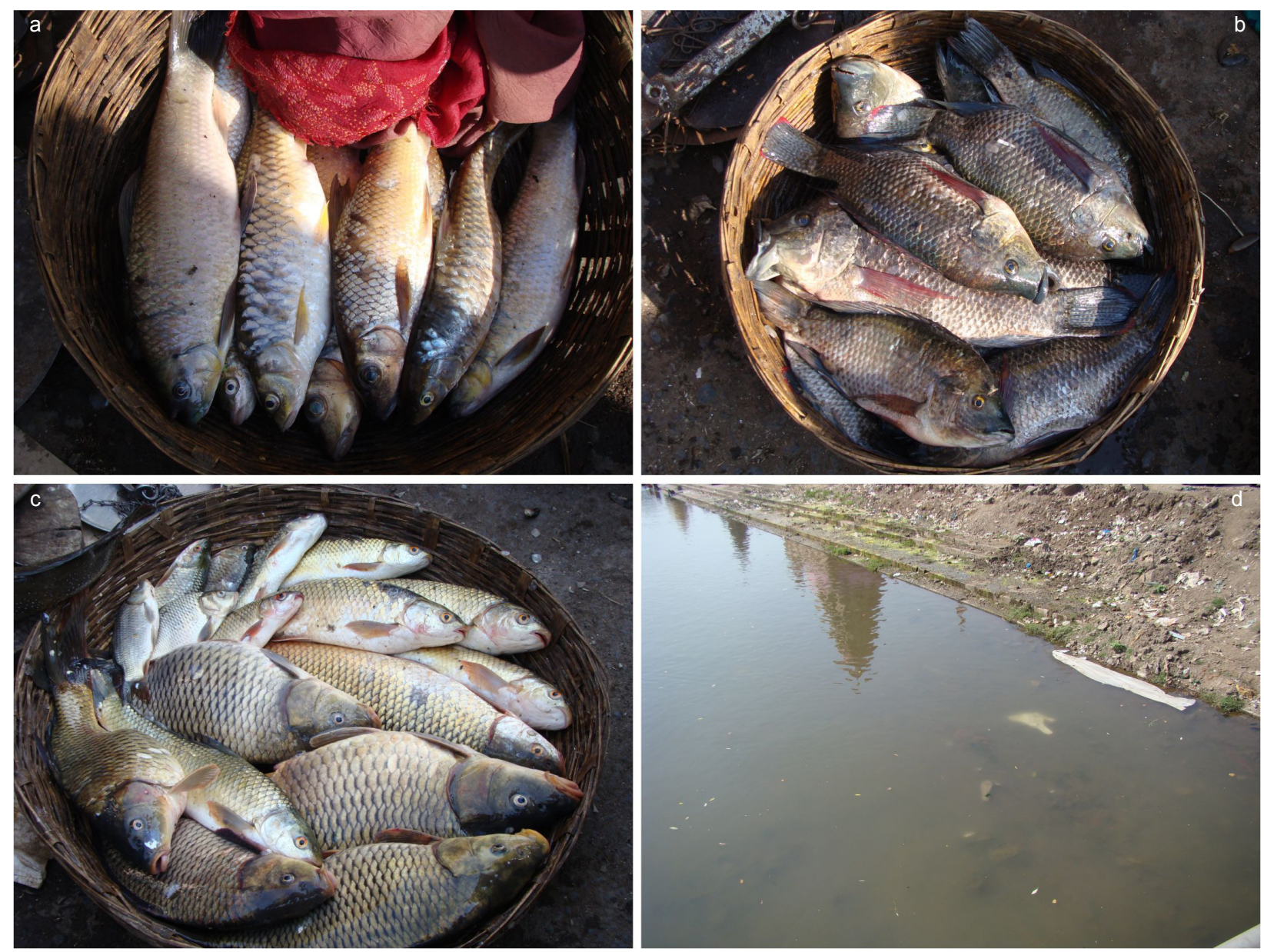

Image 3. Major threats to the fish fauna of Krishna River at Wai.

a - Heavy harvesting of threatened species such as Schismatorhynchos nukta, Tor khudree and Tor mussullah;

b - introduced alien species such as Oreochromis mossambicus; c - culturing of transplanted fish species such as

Cyprinus carpio and Cirrhinus mrigala in Dhom reservoir; some of which have established populations even in the river below the dam; $d$ - pollution of the river stretch.

Hypselobarbus curmuca as EN owing to the fact that the species is threatened throughout its range by habitat destruction and targeted fishing, which might have lead to population decline by more than $50 \%$ in the last 10 years whereas, Raghavan \& Ali (2011) assessed Hypselobarbus kolus as VU based on population decline of $30-40 \%$ in the wild populations within last ten years due to overexploitation, destructive fishing practices and decline in the quality of habitat. In the book by Jayaram (2010), considered H. kolus a junior subjective synonym of $H$. curmuca and the genus is considered valid as Gonoproktopterus. If both $H$. kolus and H. curmuca are indeed one and the same species then the species $G$. curmuca might have a different threat status or it might be assessed as Least Concern (LC) based on the wide distribution. This uncertainty in taxonomic status and its effects on assigning the threat status bolsters the arguments raised by Molur et al. (2011) and Raghavan et al. (2012) that resolving the taxonomic issues is essential for assigning conservation status of a species. Nevertheless, G. curmuca is abundant in the study area although it is also subjected to heavy harvest. In the absence of detailed studies regarding the fishing trends it is difficult to state whether the harvesting of this species in the study area is sustainable or not.

The fish fauna of Krishna River at Wai is threatened due to several factors including heavy harvesting of fish resources, competition and predation by introduced species and habitat degradation due to organic and inorganic pollution (Image 3). In the Upstream, the river is also threatened by tourism and associated recreational activities. Most of the river stretch is affected by organic and inorganic pollution seeping 
from adjacent agricultural lands. Especially in Wai the river is polluted due to organic and inorganic pollutants contributed by household waste, recreational activities and tourism. Even though the effect of these pollutants on the fish fauna of this area is not exactly known, decline in many endemic and threatened species could be partially attributed to them.

In the light of global decline in biodiversity, especially in areas like the Western Ghats, which harbors rich diversity of endemic freshwater fish, systematic conservation plans to monitor and conserve freshwater fish of Wai area are essential. Because Wai also hosts a number of globally threatened species, there is a need for site based management plans in this area. We suggest following management plans: (i) check on the fishing activities in the backwaters of Dhom Dam especially during the breeding season (May to August), (ii) monitoring of the water quality and check on the release of untreated organic and inorganic wastes in the river, (iii) promotion of environment friendly agricultural practices along the river banks, and, (iv) strict regulations regarding tourism related anthropogenic stressors.

\section{REFERENCES}

Abraham, R. (2011). Hypselobarbus curmuca. In: IUCN 2011. IUCN Red List of Threatened Species. Version 2011.2. <www.iucnredlist.org>. Downloaded on 03 March 2012.

Arunachalam, M., A. Sankaranarayanan, A. Manimekalan, R. Soranam \& J.A. Jonson (2002). Fish fauna of some streams and rivers in the Western Ghats of Maharashtra. Journal of the Bombay Natural History Society 99(2): 337-341.

Dahanukar, N. (2011a). Labeo potail. In: IUCN 2011. IUCN Red List of Threatened Species. Version 2011.2. <www. iucnredlist.org>. Downloaded on 03 March 2012.

Dahanukar, N. (2011b). Parapsilorhynchus discophorus. In: IUCN 2011. IUCN Red List of Threatened Species. Version 2011.2. <www.iucnredlist.org>. Downloaded on 03 March 2012.

Dahanukar, N. (2011c). Schismatorhynchos nukta. In: IUCN 2011. IUCN Red List of Threatened Species. Version 2011.2. <www.iucnredlist.org>. Downloaded on 03 March 2012.

Dahanukar, N. \& R. Raghavan (2011). Hypselobarbus mussullah. In: IUCN 2011. IUCN Red List of Threatened Species. Version 2011.2. <www.iucnredlist.org>. Downloaded on 03 March 2012.

Dahanukar, N., M. Paingankar, R.N. Raut \& S.S. Kharat
(2012). Fish fauna of Indrayani River, northern Western Ghats, India. Journal of Threatened Taxa 4(1): 2310-2317.

Eschmeyer, W.N. (ed.) (2012) Catalog of Fishes electronic version (15 March 2012). http://research.calacademy.org/ research/ichthyology/catalog/fishcatmain.asp. Accessed on 8 April 2012.

Ghate, H.V., V.M. Pawar \& B.E. Yadav (2002). Note on cyprinoid fish Schismatorhynchos (Nukta) nukta (Sykes) from the Krishna drainage, Western Ghats. Zoos' Print Journal 17(7): 830-831.

IUCN (2011). IUCN Red List of Threatened Species. Version 2011.1. <www.iucnredlist.org>. Downloaded on 24 September 2011.

Jadhav, B.V., S.S. Kharat, R. Raut, M. Paingankar \& N. Dahanukar (2011). Freshwater fish fauna of Koyna River, Northern Western Ghats, India. Journal of Threatened Taxa 3(1): 1449-1455.

Jayaram, K.C. (1991). Revision of The Genus Puntius Hamilton from The Indian Region (Pisces: Cypriniformes, Cyprinidae, Cyprininae). Occasional Paper No. 135. Records of the Zoological Survey of India, Kolkata. 178pp.

Jayaram, K.C. (1995). The Krishna River System: A Bioresources Study. Occasional Paper No. 160. Records of Zoological Society of India, 167pp.

Jayaram, K.C. (2010). The Freshwater Fishes of The Indian Region. Second Edition. Narendra Publishing House, Delhi, 616pp.

Jayaram, K.C. \& J.J. Dhas (2000). Revision of The Genus Labeo from Indian Region with A Discussion on Its Phylogeny and Zoogeography. Occasional Paper No. 183. Records of the Zoological Survey of India, Kolkata, $143 \mathrm{pp}$.

Jayaram, K.C. \& A. Sanyal (2003). A Taxonomic Revision of The Fishes of The Genus Mystus Scopoli (Family: Bagridae). Occasional Paper No. 207. Records of the Zoological Survey of India, Kolkata, 136pp.

Kharat,S.S.,N.Dahanukar,R.Raut\&M.Mahabaleshwarkar (2003). Long term changes in freshwater fish species composition in North Western Ghats, Pune District. Current Science 84(6): 816-820.

Menon, A.G.K. (1987). The Fauna of India and Adjacent Countries, Pisces, Vol. 4, Teleostei-Cobitoidea, Part 1, Homalopteridae. Zoological Survey of India, Kolkata, $259 \mathrm{pp}$.

Menon, A.G.K. (1999). Check List Freshwater Fishes of India. Occasional Paper No. 175. Records of the Zoological Survey of India, Kolkata. 366pp.

Molur, S., K.G. Smith, B.A. Daniel \& W.R.T. Darwall (compilers) (2011). The Status and Distribution of Freshwater Biodiversity in The Western Ghats, India. Cambridge, UK and IUCN, Gland, Switzerland and Zoo Outreach Organisation, Coimbatore, India, 116pp.

Raghavan, R. (2011). Tor khudree. In: IUCN 2011. IUCN Red List of Threatened Species. Version 2011.2. <www. iucnredlist.org $>$. Downloaded on 03 March 2012.

Raghavan, R. \& A. Ali (2011). Hypselobarbus kolus. In: 
IUCN 2011. IUCN Red List of Threatened Species. Version 2011.2. <www.iucnredlist.org>. Downloaded on 03 March 2012.

Raghavan, R., A. Ali, N. Dahanukar \& A. Rosser (2011). Is the Deccan Mahseer, Tor khudree (Sykes) fishery in the Western Ghats Hotspot sustainable? A participatory approach to assessment. Fisheries Research 110(1): 29-38.

Raghavan, R., N. Dahanukar, K. Krishnakumar, A. Ali, S. Solomon, M.R. Ramprasanth, F. Baby, B. Pereira, J. Tharian \& S. Philip (2012). Western Ghats fish fauna in peril: are pseudo conservationist attitudes to be blamed?
Current Science 102(6): 835-837.

Silas, E.G. (1953). Notes on the fishes from Mahabaleshwar and Wai (Satara District, Bombay State). Journal of the Bombay Natural History Society 51(3): 579-589.

Srithar, R.T. \& K.C. Jayaram (1990). On a new species of Salmostoma Swainson (Cyprinidae: Cultrinae) form Dhom reservoir, Satara District, Maharashtra. Journal of the Bombay Natural History Society 87(2): 272-274.

Talwar, P.K. \& A.G. Jhingran (1991). Inland Fishes of India and Adjacent Countries. Oxford-IBH Publishing Co. Pvt. Ltd., New Delhi, 1158pp. 